\title{
Relationship Between Mode I Fracture Toughness and Strength Parameters of Brittle and Plastic Coal and the Fracture Process
}

\section{Zhe Ma ( $D$ 853024963@qq.com )}

xi'an university of science and technology

Jing Chai

Xi'an University of Science and Technology

Jianfeng Yang

Xi'an University of Science and Technology

Dingding Zhang

Xi'an University of Science and Technology

Yongliang Liu

Xi'an University of Science and Technology

Yibo Ouyang

Xi'an University of Science and Technology

\section{Research}

Keywords: Roadway, Plastic zone, Brittleness, DIC, Mode I fracture toughness, Nonlinear fracture

Posted Date: August 30th, 2021

DOI: https://doi.org/10.21203/rs.3.rs-820677/v1

License: () (1) This work is licensed under a Creative Commons Attribution 4.0 International License.

Read Full License 


\section{Relationship between mode I fracture toughness and strength parameters of brittle and plastic coal and the fracture process}

Zhe Ma ${ }^{1}$, Jing Chai ${ }^{1,2}$, Jianfeng Yang ${ }^{1,2}$ Dingding Zhang ${ }^{1,2}$ Yongliang Liu ${ }^{1,2}$ Yibo Ouyang ${ }^{1,2}$

(1. School of Energy, Xi'an University of Science and Technology, Xi'an 710054; 2. Western key Laboratory of

Mine Mining and disaster Prevention, Ministry of Education, Xi'an University of Science and Technology, Xi'an

China 710054.)

Abstract: Underground roadway excavation will form a plastic circle within the surrounding rock. The brittleness and plasticity of coal at different positions relative to the plastic circle are significantly different. Through drilling and sampling of the roadway roof, the $\mathrm{K}_{\mathrm{IC}}$ and strength parameters of coal with different brittle and plastic at different positions of roadway plastic circle were tested. Coal samples were collected at borehole depths of $0.7 \mathrm{~m}, 2.5 \mathrm{~m}$, and $4.4 \mathrm{~m}$, which are respectively located in the plastic circle, on the edge of the plastic circle, and outside of the plastic circle. The $\mathrm{K}_{\mathrm{IC}}$ and strength parameters of coal at different positions relative to the plastic zone are quite different. The $\mathrm{K}_{\mathrm{IC}}$ of coal at $0.7 \mathrm{~m}, 2.5 \mathrm{~m}$, and $4.4 \mathrm{~m}$ borehole depth is 0.2436 $\mathrm{MPa}, 0.1736 \mathrm{MPa}$, and $0.1504 \mathrm{MPa}$, respectively. With increasing borehole depth, the compressive strength of coal increases, and the tensile strength decreases. For specimens with high compressive strength, the elastic modulus is relatively large, but Poisson ratio is relatively small. The linear fitting of $\mathrm{K}_{\mathrm{IC}}$ and strength parameters of coal shows that the $\mathrm{K}_{\mathrm{IC}}$ of coal negatively correlates with compressive strength and elastic modulus; the $\mathrm{K}_{\mathrm{IC}}$ of coal positively correlates with tensile strength and Poisson's ratio. Compared with the compressive strength, the tensile strength of coal has a stronger influence on the $\mathrm{K}_{\mathrm{IC}}$ and cracks can more easily expand with increasing tensile stress. Compared with the elastic modulus, Poisson's ratio has a stringer influence on crack growth and has a stronger correlation with the $\mathrm{K}_{\mathrm{IC}}$ of coal. And the relationship between the brittle index and the $\mathrm{K}_{\mathrm{IC}}$ is studied. The deeper the borehole is, the greater the brittleness index of coal is. There is a linear relationship between brittleness and $\mathrm{K}_{\mathrm{IC}}$. $\mathrm{K}_{\mathrm{IC}}$ can be characterized by coal brittleness. Digital image correlation (DIC) was used to analyze the mode I crack growth characteristics and nonlinear failure process of semicircular three-point bending specimens. The accurate crack initiation point $\left(\mathrm{P}_{\mathrm{S}}\right)$ and the critical crack tip opening displacement $\left(\mathrm{W}_{0}\right)$ of different brittle plastic coals are obtained. Compared with experimental results and numerical simulation, the method for calculating the $\mathrm{W}_{0}$ in this paper is more accurate. By using this method defined in this paper, the $\mathrm{W}_{0}$ of coal at $0.7 \mathrm{~m}, 2.5 \mathrm{~m}$, and $4.4 \mathrm{~m}$ borehole depth are $0.0149 \mathrm{~mm}$, $0.0138 \mathrm{~mm}$, and $0.0115 \mathrm{~mm}$, respectively. Mode I cracks in coal with stronger brittleness outside the plastic zone are easier to propagate. The non-linear fracture process of coal with stronger plasticity is more significant at shallow depths, and the load at the Ps point at $0.7 \mathrm{~m}$ borehole depth is only $64.05 \%$ of the peak load. With increasing borehole depth, the more brittle the coal is, the closer it is to elastic failure. The load at the $\mathrm{P}_{\mathrm{S}}$ point of coal at $4.4 \mathrm{~m}$ borehole depth is $98.07 \%$ of the peak load, proving the importance of nonlinear fracture behavior analysis of coal. This study is significant to analyzing the crack propagation behavior of coal at different positions relative to the plastic circle of roadway and to analyzing the mechanism and features of different forms of roadway failures like roof fall and rock burst. 
Key words: Roadway; Plastic zone; Brittleness; DIC; Mode I fracture toughness; Nonlinear fracture;

\section{Introduction}

In order to mine underground coal, a large number of roadways must be excavated hundreds of meters or even kilometers away from the surface, of which $95 \%$ are coal roadways. ${ }^{1-4}$ After roadway excavation, the in-situ stress around the roadway will redistribute, resulting in plastic enhancement of the coal within a certain distance from the roadway surface, forming a surrounding rock plastic circle. The coal in the plastic circle is relatively soft and can deform greatly without being totally destroyed. The coal outside the plastic circle remains relatively hard and brittle, which can easily accumulate energy and collapse. The strength parameters and failure forms inside and outside the plastic circle are different. ${ }^{5-7}$ Under in-situ stress, different forms of roadway disasters such as large deformation, roof fall and rock burst can occur withing a coal roadway, which seriously threatens production safety. Micro crack propagation leads to coal failure. Therefore, the study of coal fracture characteristics is significant to the theoretical research and practical mining. The rock and coal around the roadway are commonly in the state of compression and shear. Based on this, ${ }^{8-13}$ Lajtail and others have conducted significant research on the crack propagation characteristics of coal under compression and shear stress. The crack tip is thought to remain in a state of tension and shear stress at that time. The turning of the crack and the separation of the fracture surface are all due to the tensile stress exceeding the bonding force between atoms, which leads to mode I failure. ${ }^{14-15}$ Therefore, testing strength parameters and mode I fracture toughness $\left(\mathrm{K}_{\mathrm{IC}}\right)$ of coal at different positions within the plastic circle, analyzing their internal relations, and the crack propagation process of coal to understand the mechanism and characteristics of different types of surrounding rock disasters, as well as implement support design and disaster prevention protocols.

In fracture mechanics, ${ }^{16-17}$ fracture toughness $\left(\mathrm{K}_{\mathrm{C}}\right)$ characterizes the fracture resistance of materials. ${ }^{18-19}$ When the tensile stress reaches a maximum, the crack tip opening displacement(CTOD) is called $\mathrm{W}_{0}$. Like the $\mathrm{K}_{\mathrm{C}}$, the $\mathrm{W}_{0}$ is the only material constant characterizing the fracture resistance of materials when the yield zone range is small. That is to say, the geometric parameters and loading conditions of cracks in different samples can be completely different; however, as long as the $\mathrm{K}_{\mathrm{C}}$ or the $\mathrm{W}_{0}$ are the same, the stress field, displacement field and strain energy field at the crack tip are exactly the same. Therefore, $\mathrm{W}_{0}$ is a reliable parameter for measuring crack stability.

Linear elastic fracture mechanics (LEFM) is a proved effective theoretical method for studying crack propagation in solid materials with primary cracks or defects. No one pays attention to the nonlinear region at the crack tip when people use linear elastic fracture theory to analyze crack propagation in materials. However, in practice, the stress is large at the crack tip. A series of nonlinear behaviors such as microcrack propagation and material plastic deformation may occur near the crack tip. For most solid materials, the nonlinear region cannot be ignored relative to the original crack size. For solid materials, the special region before the crack tip is called for fracture process zone (FPZ). ${ }^{20}$ The fracture process zone, also known as the nonlinear softening region, 
is a series of parallel viscous microcracks and is used to characterize the characteristic behavior of progressive softening in a given region before the crack tip. During fracturing, a series of nonlinear phenomena such as microcrack propagation, nonlinear deformation, as well as contact and friction on crack surface occur in this area, which are characterized by irreversible nonlinear damage and even material failure.

Some researchers ignore FPZ length and use LEFM to study the fracture characteristics of coal ${ }^{21-22}$. However, it cannot reflect the nonlinear response of the materials without FPZ. ${ }^{23}$ In coal, crack propagation occurs before the maximum load. It is affected by FPZ before the notch tip. Therefore, it is inappropriate to consider the CTOD to be $\mathrm{W}_{0}$ when stress is maximum. ${ }^{24-27}$ Some scholars have obtained $\mathrm{W}_{0}$ using an empirical formula, as well as numerical simulations in the study of quasi brittle materials like concrete and coal. However, the strength parameters of coal around the roadway are quite different. Using these two methods to determine a unique critical crack tip opening displacement value for the coal surrounding a roadway is not appropriate. Therefore, accurately determining $\mathrm{W}_{0}$ and crack initiation load as well as obtaining the fracture process zone evolution process is crucial.

In this article, For the coal of different locations in the roadway plastic circle, the fracture toughness and strength parameters are tested and the relationship between them was analyzed. Furthermore, the accurate crack initiation stress and $\mathrm{W}_{0}$ of prefabricated mode I cracks in brittle and plastic coal are studied by digital image correlation (DIC) technology. Also, the evolution of the FPZ is analyzed. This work provides a reference for studying the fracture features around coal roadway and analyzing the mechanism and characteristics of roadway failure.

\section{Experimental Apparatus and Methodology}

\subsection{Experimental Samples}

The roof of the haulage drift of Huojitu well in Daliuta coal mine, Shaanxi Province, China was drilled upward for sampling. Before sampling, the thickness of the plastic circle was determined to be $2.1 \mathrm{~m}$ by theoretical calculation and numerical simulation. Samples were collected from inside the plastic circle, on the edge of the plastic circle and outside the plastic circle. Finally, the vertical borehole depth was $5 \mathrm{~m}$, and coal samples at a vertical distance of $0.7 \mathrm{~m}, 2.5 \mathrm{~m}$, and $4.4 \mathrm{~m}$ from the orifice were processed into 9 groups of samples. Cylindrical specimens were under uniaxial loading (Fig. 1a), disk samples were used for the splitting experiment (Fig. 1b), and semicircular specimens were used for SCB experiment (Fig. 1c). The crack in the semicircular specimen used for SCB test was prefabricated using a $0.5 \mathrm{~mm}$ diamond impregnated fine steel wire and a speckle was made on the front surface to test the surface strain and displacement. The parallelism deviation and diameter deviation of two end faces of all test pieces were not greater than $0.1 \mathrm{~mm}$ and as inspected using a dial indicator and vernier caliper, respectively. Samples were dried for one day before beginning the experiment. The size and number are shown in Table 1. 


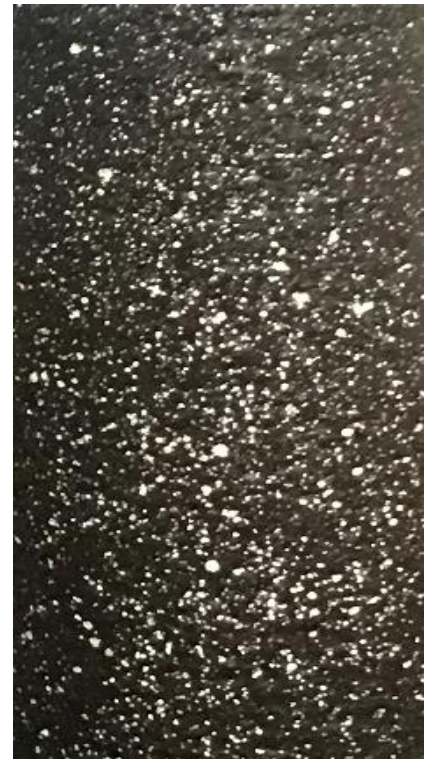

Fig. 1a

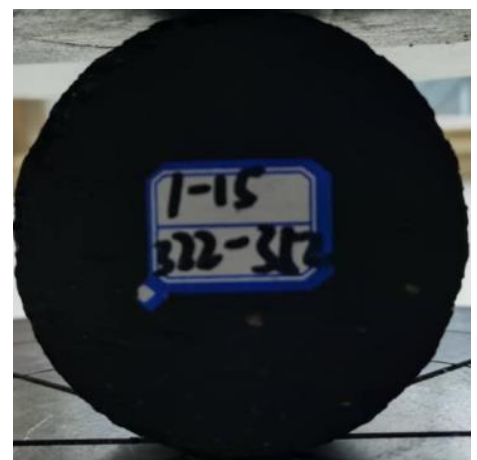

Fig. 1b

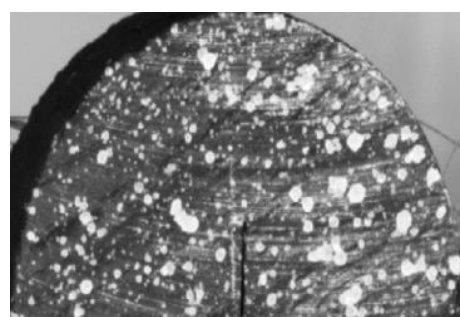

Fig. 1c

Fig. 1 Coal specimens

Table 1 Sample dimensions

\begin{tabular}{cccccc}
\hline \multirow{2}{*}{ Experiments } & Specimen shape & Borehole depth $/ \mathrm{m}$ & $\begin{array}{c}\text { Height } \\
/ \mathrm{mm}\end{array}$ & $\begin{array}{c}\text { Diameter } \\
/ \mathrm{mm}\end{array}$ & Number \\
\hline \multirow{2}{*}{ Uniaxial } & cylindrical & 0.7 & 140 & 70 & 2 \\
compression & specimens & 2.5 & 140 & 70 & 2 \\
& & 4.4 & 140 & 70 & 2 \\
Brazilian splitting & disk specimens & 0.7 & 30 & 70 & 3 \\
& & 2.5 & 30 & 70 & 3 \\
Semi-circular bend & semi-circular & 4.4 & 30 & 70 & 2 \\
(SCB) & specimens & 0.7 & 25 & 70 & 2 \\
& & 4.4 & 25 & 70 & 2 \\
\hline
\end{tabular}

\subsection{Working principles of DIC}

Optical means like ESPI ${ }^{28}$ (Hag et al. 2010), ${ }^{29}$ BOTDA (Chai et al. 2020) and ${ }^{30}$ DIC (Li et al.2017) can been measured crack propagation of materials. Significantly, due to the non-contact, fast measurement speed, and high accuracy, the displacement field and strain field can be well measured by DIC. Therefore, DIC technology can well study the crack propagation behavior, including ${ }^{31-34}$ I fracture inducing materials, ${ }^{35}$ mixed mode fracture in sandstone, and ${ }^{36}$ fracture characteristics at a rock-concrete interface. 

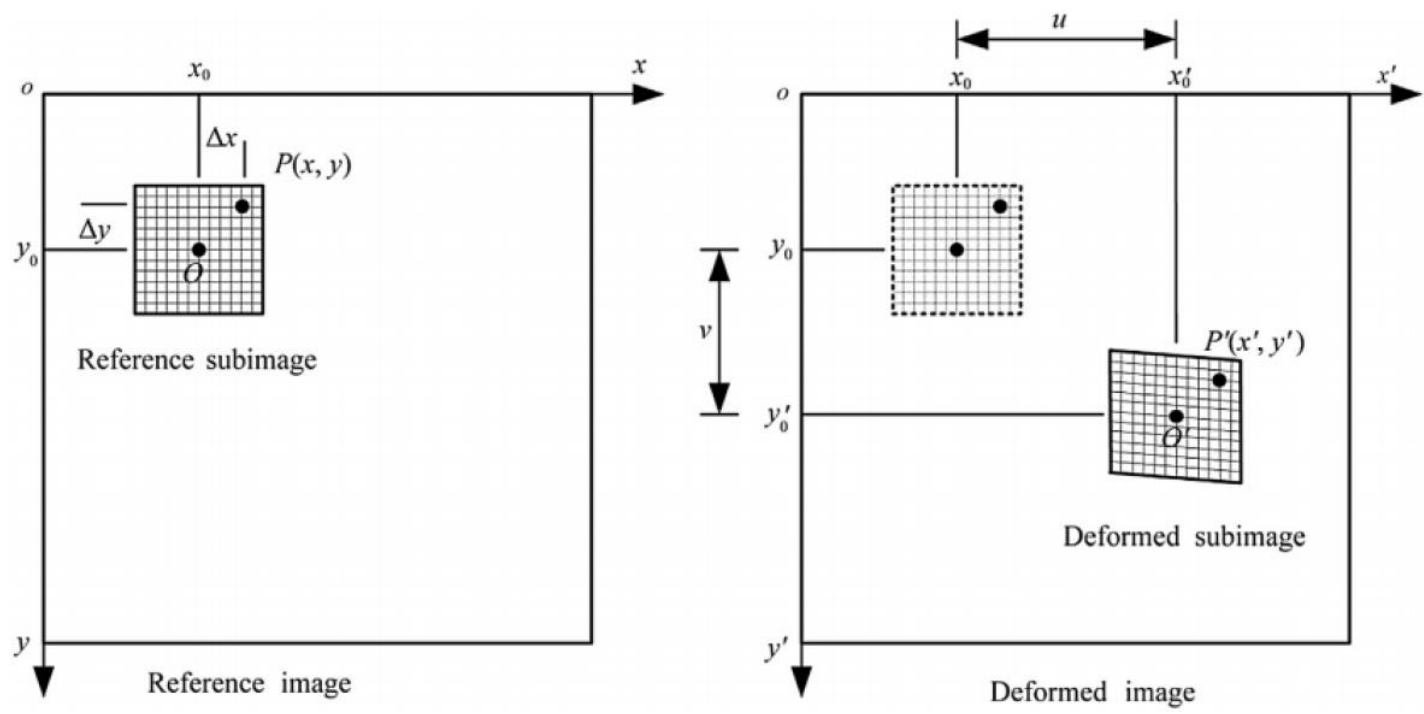

Fig. 2 Schematics of the reference and deformed subsets

Obtain images at different stages of experiment, the displacement (Fig. 2) can be calculated by comparing the gray values of images in different stages. The correlation coefficient is defined as:

$$
\begin{gathered}
C(X)=\frac{\sum_{i=1}^{m} \sum_{j=1}^{m}\left[f\left(x_{i}, y_{j}\right)-\bar{f}\right] \cdot\left[g\left(x_{i}^{*}, y_{j}^{*}\right)-\bar{g}\right]}{\sqrt{\sum_{i=1}^{m} \sum_{j=1}^{m}\left[f\left(x_{i}, y_{j}\right)-\bar{f}\right]^{2} \cdot \sum_{i=1}^{m} \sum_{j=1}^{m}\left[g\left(x_{i}^{*}, y_{j}^{*}\right)-\bar{g}\right]^{2}}} \\
x^{*}=x+u+\frac{\partial u}{\partial x} \Delta x+\frac{\partial u}{\partial y} \Delta y \\
y^{*}=y+v+\frac{\partial v}{\partial x} \Delta x+\frac{\partial v}{\partial y} \Delta y
\end{gathered}
$$

where $\mathrm{X}=(\mu, v, \partial \mu / \partial x, \partial \mu / \partial y, \partial v / \partial x, \partial v / \partial y)$ containing six deformation parameters, $\mathrm{f}(\mathrm{x}, \mathrm{y})$ is the gray-level value at coordinate $(\mathrm{x}, \mathrm{y})$ for the reference image, $\mathrm{g}\left(\mathrm{x}^{*}, \mathrm{y}^{*}\right)$ is the gray-level value at coordinate $\left(\mathrm{x}^{*}, \mathrm{y}^{*}\right)$ for the target image, and $\bar{f}$ and $\bar{g}$ are the average gray value of the image $\mathrm{f}(\mathrm{x}, \mathrm{y})$ and $\mathrm{g}\left(\mathrm{x}^{*}, \mathrm{y}^{*}\right)$, respectively.

\section{Results and Discussion}

\subsection{Compressive and tensile strength of coal}

The uniaxial compressive strength, tensile strength, elastic modulus and Poisson's ratio of coal at multiple borehole depths are obtained (Table $2 \&$ Table 3), which reflect the mechanical properties of coal.

Table 2 Compression strength test results for the coal 


\begin{tabular}{|c|c|c|c|c|c|c|c|c|}
\hline \multirow{10}{*}{$\begin{array}{c}\text { Uniaxial } \\
\text { compression }\end{array}$} & $\begin{array}{l}\text { Sampling } \\
\text { positions }\end{array}$ & $\begin{array}{l}\text { Borehole } \\
\text { depth /m }\end{array}$ & $\begin{array}{l}\text { Serial } \\
\text { number }\end{array}$ & $\begin{array}{l}\text { Height } \\
\text { /mm }\end{array}$ & $\begin{array}{c}\text { Diameter } \\
\text { /mm }\end{array}$ & $\begin{array}{l}\text { Compression } \\
\text { strength } / \mathrm{MPa}\end{array}$ & $\begin{array}{l}\text { Elastic } \\
\text { modulus } \\
\text { /MPa }\end{array}$ & $\begin{array}{c}\text { Poisson's } \\
\text { ratio }\end{array}$ \\
\hline & \multirow{3}{*}{$\begin{array}{c}\text { In the plastic } \\
\text { circle }\end{array}$} & 0.7 & 1 & 140.06 & 69.91 & 6.25 & 965 & 0.29 \\
\hline & & 0.7 & 2 & 140.07 & 70.02 & 7.84 & 1143 & 0.26 \\
\hline & & & \multicolumn{3}{|c|}{ Average } & 7.05 & 7.05 & 0.275 \\
\hline & \multirow{3}{*}{$\begin{array}{c}\text { Edge of } \\
\text { plastic circle }\end{array}$} & 2.5 & 3 & 140.08 & 69.96 & 8.06 & 1126 & 0.25 \\
\hline & & 2.5 & 4 & 139.93 & 69.94 & 9.12 & 1431 & 0.22 \\
\hline & & & \multicolumn{3}{|c|}{ Average } & 8.59 & 8.59 & 0.235 \\
\hline & \multirow{3}{*}{$\begin{array}{l}\text { Out the } \\
\text { plastic circle }\end{array}$} & 4.4 & 5 & 140.04 & 69.96 & 9.78 & 1875 & 0.19 \\
\hline & & 4.4 & 6 & 139.98 & 70.06 & 15.37 & 2637 & 0.21 \\
\hline & & & \multicolumn{3}{|c|}{ Average } & 12.58 & 12.58 & 0.20 \\
\hline
\end{tabular}

Table 3 Brazilian splitting test results for the coal

\begin{tabular}{|c|c|c|c|c|c|c|c|}
\hline \multirow{13}{*}{$\begin{array}{l}\text { Brazilian } \\
\text { splitting }\end{array}$} & Sampling positions & Borehole depth/m & $\begin{array}{c}\text { Serial } \\
\text { number }\end{array}$ & $\begin{array}{c}\text { Thickness } \\
\text { /mm }\end{array}$ & $\begin{array}{l}\text { Diameter } \\
\qquad / \mathrm{mm}\end{array}$ & $\begin{array}{c}\text { Peak } \\
\text { loading } \\
\text { /KN }\end{array}$ & $\begin{array}{c}\text { tensile } \\
\text { strength } / \mathrm{MPa}\end{array}$ \\
\hline & & 0.7 & 1 & 30.08 & 69.94 & 6.16 & 1.84 \\
\hline & & 0.7 & 2 & 29.95 & 69.97 & 5.09 & 1.53 \\
\hline & in the prastic circle & 0.7 & 3 & 30.02 & 70.03 & 4.98 & 1.49 \\
\hline & & & Average & & & 5.41 & 1.62 \\
\hline & & 2.5 & 4 & 29.93 & 70.02 & 3.46 & 1.04 \\
\hline & Edge of plastic & 2.5 & 5 & 30.04 & 69.96 & 4.10 & 1.23 \\
\hline & circle & 2.5 & 6 & 29.97 & 69.94 & 3.57 & 1.07 \\
\hline & & & Average & & & 3.84 & 1.15 \\
\hline & & 4.4 & 7 & 30.03 & 69.91 & 3.25 & 0.98 \\
\hline & Out the plastic & 4.4 & 8 & 29.96 & 70.02 & 3.04 & 0.91 \\
\hline & circle & 4.4 & 9 & 29.92 & 70.04 & 2.97 & 0.89 \\
\hline & & & Average & & & 3.09 & 0.92 \\
\hline
\end{tabular}

The strength parameters are normalized using the strength parameters of coal at a $0.7 \mathrm{~m}$ borehole depth. And the variation law of strength parameter at different positions relative to the plastic area is obtained. As the borehole depth increasing, the compressive strength and elastic modulus of the specimen increase, and the tensile strength and Poisson's ratio decrease (Fig. 3). Compared with the strength parameters of coal at the borehole depth of $0.7 \mathrm{~m}$, the compressive strength at the $\mathrm{d}$ borehole depth of $4.4 \mathrm{~m}$ increased by $78 \%$, the elastic modulus increased by $114 \%$, the tensile strength decreased by $43 \%$, and the Poisson's ratio decreased by $28 \%$. The strength parameters of coal in different areas of plastic circle are quite different. 


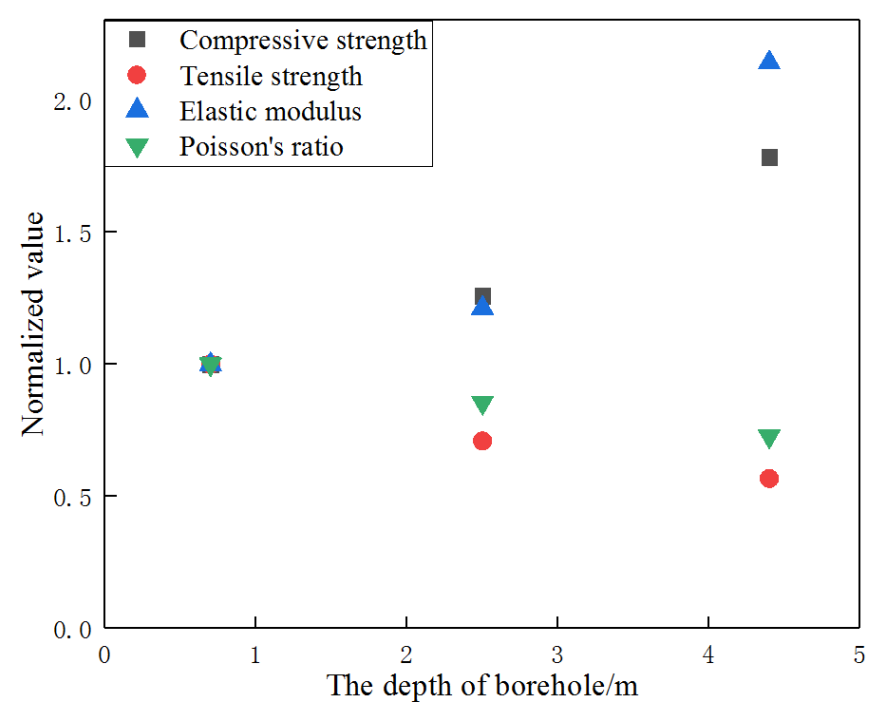

Fig. 3 Variation of strength parameters with different borehole depth

\subsection{Measurement of mode I fracture toughness (KIC)}

The $\mathrm{K}_{\mathrm{IC}}$ of coal is got using the SCB test for evaluating the crack propagation ability of coal at different positions relative to the plastic circle. The direction of prefabricated crack is consistent with the loading direction, with a length of $12.25 \mathrm{~mm}$ (Fig. 4). The ratio of crack length to semicircle radius $(\mathrm{a} / \mathrm{R})$ is 0.35 . The ratio of the distance between the lower support point and the crack to the semicircle radius $(\mathrm{S} / \mathrm{R})$ is 0.5 .
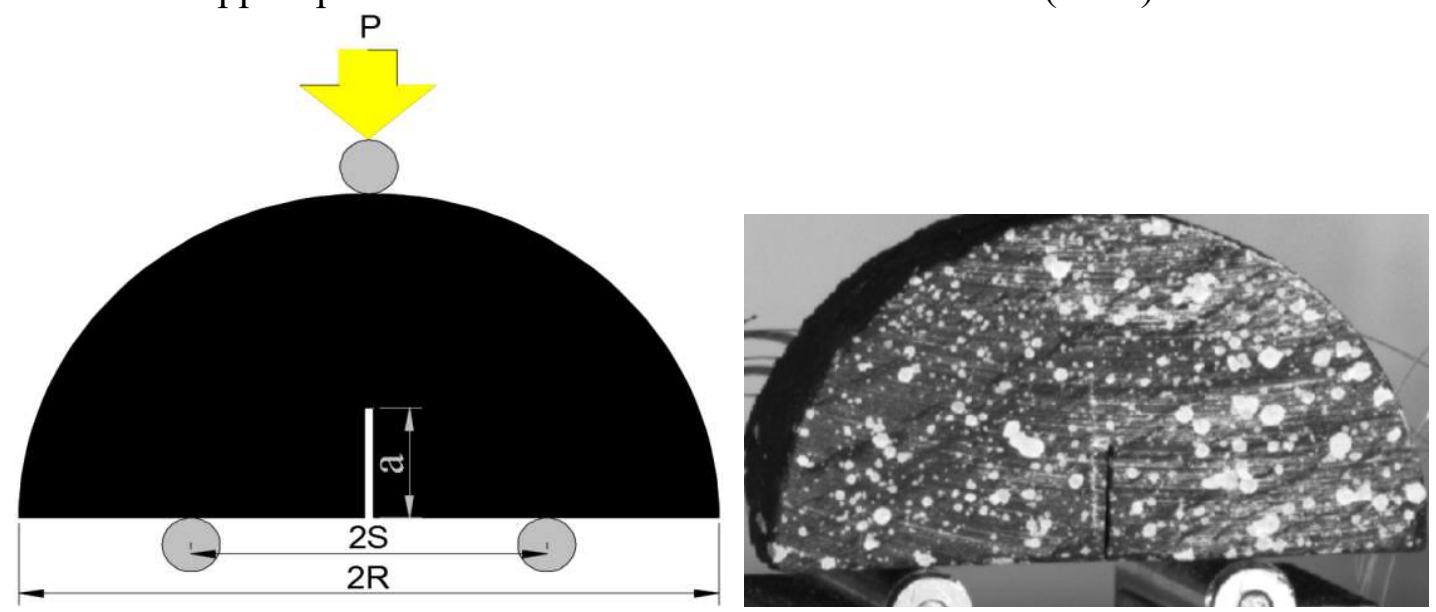

Fig 4 loading mode of SCB specimens

The fracture toughness was measured by SCB test. The external force $\mathrm{P}$ is provided by testing machine, located directly above the crack and coaxial with the crack. The SIF of mode $\mathrm{I}$ is represented by $\mathrm{K}_{\mathrm{I}}$ and the $\mathrm{K}_{\mathrm{I}}$ value corresponding to maximum stress is recorded as the fracture toughness $\mathrm{K}_{\mathrm{IC}}$. The SIF of a SCB sample is given by ${ }^{37}$ ayatollahi and aliha:

$$
K_{I}=\frac{P \sqrt{\pi \alpha}}{2 R B} Y_{I}\left(\frac{\alpha}{R}, \frac{S}{R}, \beta\right)
$$

where $p$ is the compressive force, $\beta$ is the angle of the prefabricated crack line from the vertical direction, and $\mathrm{B}$ is the thickness. $\mathrm{Y}_{\mathrm{I}}$ is the geometric factor of mode I 
through geometric parameters $\beta, \quad \alpha / \mathrm{R}$ and $\mathrm{S} / \mathrm{R}$ are calculated. For a specimen with $\beta=0^{\circ}, \alpha / R$ is $0.35, S / R$ is 0.5 , and $Y_{I}$ is 2.787 . When the compressive force reaches the maximum, the crack begins to growth, and we can calculate the fracture toughness by the formula.

Table 4 SCB test of the coal

\begin{tabular}{|c|c|c|c|c|c|c|c|c|c|}
\hline \multirow{10}{*}{$\begin{array}{l}\text { Semi-circular } \\
\text { bend } \\
\text { (SCB) }\end{array}$} & $\begin{array}{l}\text { Sampling } \\
\text { positions }\end{array}$ & $\begin{array}{l}\text { Borehole } \\
\text { depth/m }\end{array}$ & $\begin{array}{c}\text { Serial } \\
\text { number }\end{array}$ & $\begin{array}{c}\text { Thickness } \\
\text { /mm }\end{array}$ & $\begin{array}{c}\text { Diamet } \\
\text { er } \\
/ \mathrm{mm}\end{array}$ & $\begin{array}{c}\mathrm{a} \\
/ \mathrm{mm}\end{array}$ & $\beta /{ }^{\circ}$ & $\begin{array}{c}\text { Peak } \\
\text { loading } \\
\text { /N }\end{array}$ & $\begin{array}{c}\mathrm{K}_{\mathrm{IC}} \\
{[\mathrm{Mpa}} \\
\left.\mathrm{m}^{5}\right]\end{array}$ \\
\hline & In the & 0.7 & 1 & 25.02 & 69.97 & 12.23 & 0 & 821.5 & 0.2566 \\
\hline & plastic & 0.7 & 2 & 25.05 & 70.02 & 12.21 & 0 & 737.9 & 0.2305 \\
\hline & circle & & & Average & & & & 779.7 & 0.2436 \\
\hline & Edge of & 2.5 & 3 & 24.98 & 69.94 & 12.23 & 0 & 539.6 & 0.1686 \\
\hline & plastic & 2.5 & 4 & 24.95 & 69.98 & 12.26 & 0 & 555.8 & 0.1736 \\
\hline & circle & & & Average & & & & 547.7 & 0.1711 \\
\hline & Out the & 4.4 & 5 & 25.06 & 69.99 & 12.19 & 0 & 436.1 & 0.1362 \\
\hline & plastic & 4.4 & 6 & 24.93 & 70.01 & 12.22 & 0 & 481.3 & 0.1504 \\
\hline & circle & & & Average & & & & 458.7 & 0.1433 \\
\hline
\end{tabular}

Table 4 shows the $\mathrm{K}_{\mathrm{IC}}$ of coal at different positions relative to the plastic zone. The mean value of $\mathrm{K}_{\mathrm{IC}}$ of coal at $0.7 \mathrm{~m}$ borehole depth is $0.2436 \mathrm{mpa}$ m.5. They are 0.1736 mpa $\mathrm{m} .5$ and $0.1504 \mathrm{mpa} \mathrm{m.5}$ at $2.5 \mathrm{~m}$ and $4.4 \mathrm{~m}$ borehole depth, respectively, which are $29.8 \%$ and $41.2 \%$ lower than those at $0.7 \mathrm{~m}$. It shows that the crack of brittle coal is easy to expand.

\subsection{Correlation analysis between $K_{I C}$ and strength parameters}

Researchers have studied the relationship between $\mathrm{K}_{\mathrm{IC}}$ and the strength parameters of rock materials. ${ }^{38-40}$ Statistics show that there is a good linear correlation between $\mathrm{K}_{\mathrm{IC}}$ and compressive strength, and the same is true for tensile strength. Furthermore, some data fitting formulas are put forward. Table 5 shows the strength parameters and $\mathrm{K}_{\mathrm{IC}}$ of coal in this experiment. Value of both at different borehole depths are normalized using the value of coal at the $0.7 \mathrm{~m}$ borehole depth, and the variation law of each coal strength parameter at different borehole depths is obtained. The linear fitting formula is determined by taking the $\mathrm{K}_{\mathrm{IC}}$ as the dependent variable and the strength parameter as the independent variable (Fig. 5)

Table 5 Strength parameters of coal

\begin{tabular}{cccccccc}
\hline \multirow{2}{*}{ Sampling positions } & $\begin{array}{c}\text { The depth of } \\
\text { borehole } / \mathrm{m}\end{array}$ & $\begin{array}{c}\mathrm{K}_{\mathrm{IC}}[\mathrm{Mpa} \\
\mathrm{m} .5]\end{array}$ & $\begin{array}{c}\text { Compression } \\
\text { strength }\end{array}$ & $\begin{array}{c}\text { Tensile } \\
\text { strength } \\
/ \mathrm{MPa}\end{array}$ & $\begin{array}{c}\text { Elastic } \\
\text { modulus }\end{array}$ & $\begin{array}{c}\text { Poisson's } \\
\text { ratio }\end{array}$ & Brittleness \\
\hline In the plastic circle & 0.7 & 0.2436 & 7.05 & 1.62 & 1.054 & 0.275 & 18.61 \\
Edge of plastic circle & 2.5 & 0.1711 & 8.59 & 1.15 & 1.279 & 0.235 & 26.77 \\
Out the plastic circle & 4.4 & 0.1433 & 12.58 & 0.92 & 2.256 & 0.2 & 34.47 \\
\hline
\end{tabular}



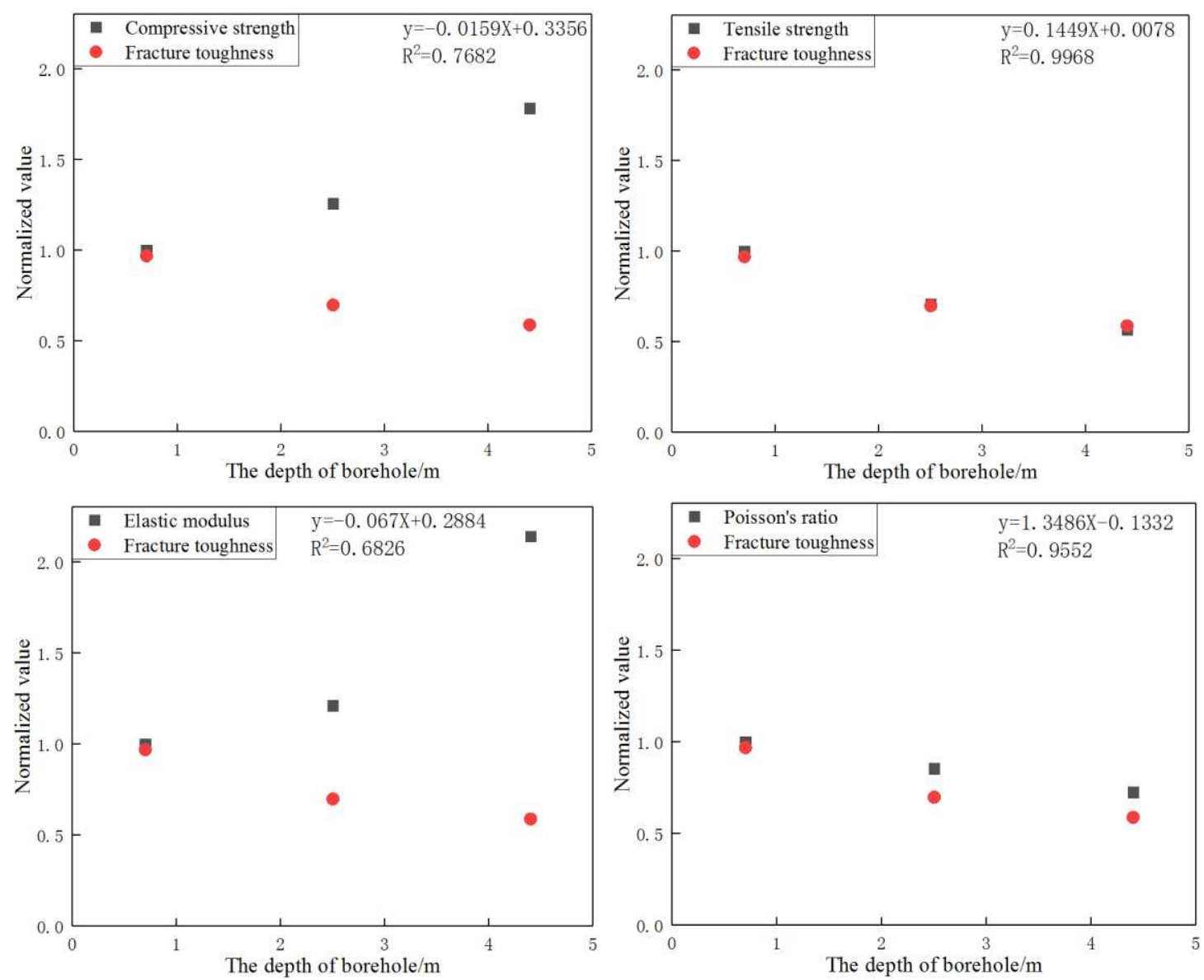

Fig. 5 Relationship between strength parameters and $\mathrm{K}_{\mathrm{IC}}$

The $\mathrm{K}_{\mathrm{IC}}$ of coal is negatively related to compressive strength, and the coefficient $\left(\mathrm{R}^{2}\right)$ is 0.7682 (Fig. 5). The $\mathrm{K}_{\mathrm{IC}}$ of coal is positively related to the tensile strength, and the coefficient $\left(\mathrm{R}^{2}\right)$ is 0.9968 . Compared with compressive strength, the tensile strength has stronger correlation with the $\mathrm{K}_{\mathrm{IC}}$ of coal. Rock molecules overcome the inter molecular tension due to either shear or tension, causing microcracks to form followed by shear slip failure or tensile failure. In compression tests, tensile failure of rock materials is still the dominant factor. Therefore, tensile cracks are likely to form in either compression or tensile tests, and coal commonly shows tensile failure, which is consistent with experimental result and engineering practice.

The $\mathrm{K}_{\mathrm{IC}}$ is negatively related to elastic modulus, and the coefficient $\left(\mathrm{R}^{2}\right)$ is 0.6826 . The $\mathrm{K}_{\mathrm{IC}}$ is positively related to Poisson's ratio, and the coefficient $\left(\mathrm{R}^{2}\right)$ is 0.9552 . Compared with the elastic modulus, Poisson's ratio a stronger influence on the $\mathrm{K}_{\mathrm{IC}}$ of coal. The elastic modulus represents a material's resistance to elastic deformation. For materials with large elastic modulus, the stress required to produce equal strain is greater. A material with a higher elastic modulus requires more stress to produce the same strain and can bear more force after failure. Therefore, the elastic modulus can reflect the bearing capacity of rock after fracturing. Poisson's ratio represents the transverse deformation ability of materials. For coal, deformation primarily occurs in the longitudinal direction. Therefore, the volume deformation of coal with a large Poisson's ratio is more significant. Poisson's ratio can also reflect the fracture ability of 
coal under stress. Coal with large Poisson's ratio is more likely to incur damage. Poisson's ratio has a stronger influence on crack growth than elastic modulus, and has a stronger correlation with the $\mathrm{K}_{\mathrm{IC}}$ of coal.

The effect of brittleness on rock mass failure mechanics is significant. A rock mass with high brittleness index is hard and brittle. Such a rock mass can easily experience local fracturing under a non-uniform stress, rapidly forming a complex fracture network. The fracture surfaces formed by the further development of the network crack lead to the collapse and separation of the surrounding rock. A rock stratum with a low brittleness index has low strength and strong plasticity; therefore, it can easily accumulate a large of amount deformation without damage. Brittleness is vitally interrelated to compressive strength, tensile strength, elastic modulus, and Poisson's ratio. Therefore, studying the relationship between coal brittleness and $\mathrm{K}_{\mathrm{IC}}$ as well as characterizing the mode I crack propagation ability of coal using coal brittleness is preferred. Based on the definition of brittleness and the failure phenomenon, scholars at home and abroad put forward nearly 20 indexes to express rock brittleness from different perspectives. ${ }^{41-54}$. At present, the primary test methods includes the stressstrain test, penetration test, and impact test. In this paper, the mathematical equation for calculating rock brittleness using the elastic modulus and Poisson's ratio proposed by Rickman ${ }^{55}$ is adopted.

$$
\begin{aligned}
& B_{R I T-E}=(E-1) /(8-1) \times 100 \\
& B_{R I T-v}=(v-0.40) /(0.15-0.40) \times 100 \\
& B_{R I T-T}=\left(B_{R I T-E}+B_{R I T-V}\right) / 2
\end{aligned}
$$

Where $\mathrm{E}$ is the elastic modulus, $\mathrm{MPa}$; $v$ is the Poisson's ratio, dimensionless; $\mathrm{B}_{\text {RIT- }}$ $\mathrm{E}$ is the brittleness characteristic parameter component corresponding to elastic modulus, dimensionless; BRIT-V is the brittleness characteristic parameter component corresponding to the Poisson's ratio, dimensionless; BRIT-T is the total brittleness characteristic parameter, dimensionless.
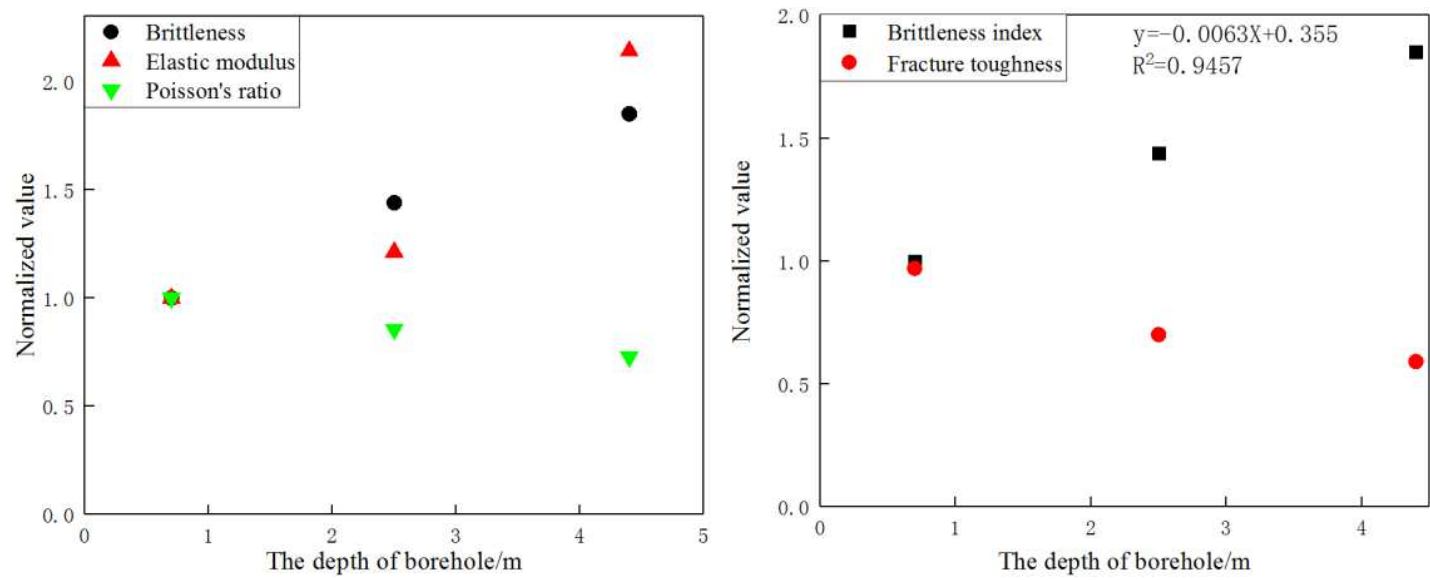

Fig. 6 Brittleness index of coal with different borehole depths

Fig. 7 The relationship between brittleness and fracture toughness of coal with different borehole depth 
With increasing borehole depth, the elastic modulus of coal increases, while Poisson's ratio decreases (Fig. 6). The brittleness index of coal at a borehole depth of $0.7 \mathrm{~m}, 2.5 \mathrm{~m}$, and $4.4 \mathrm{~m}$ is $18.61,26.77$, and 34.47 , respectively. The brittleness index values for coal at different positions around the plastic circle are significantly different. The $\mathrm{K}_{\mathrm{IC}}$ of coal is varies significantly. The brittleness of coal negatively correlates with the $\mathrm{K}_{\mathrm{IC}}$, and the determination coefficient is 0.9457 , indicating a strong correlation (Fig. 7). Therefore, the brittleness of coal can reflect the level of the $\mathrm{K}_{\mathrm{IC}}$. The greater the brittleness of coal, the smaller the mode I fracture toughness and the easier the crack propagation.

\subsection{Coal fracture process}

In the SCB test for coal, a crack is assumed to begin to propagate at the peak load point. But in fact, coal has obvious quasi-brittle fracture feature, meaning there is a FPZ before the macro crack, and the crack begins to expand before the peak load. Therefore, in this experiment, DIC is used to track the complete crack propagation process. The images at different stages are compared and the crack initiation point and FPZ evolution process are accurately obtained. By analyzing the surface displacement field of a coal sample, the $\mathrm{X}$-direction opening displacement $(\mathrm{u})$ corresponding to different loads is obtained. Fig. 8 shows the schematic diagram of the sample measurement and calculation area. Fracturing of the SCB samples is a typical modal fracture problem, which primarily focuses on the CTOD, which is perpendicular to the height direction. The images are $1280 \times 960$ pixels. A $35 * 25 \mathrm{~mm}^{2}$ computational domain is used to cover the entire ligament length. In the computational domain, several horizontal lines are used to compute CTOD. The prefabricated crack tip marks the initial horizontal line, and subsequent horizontal lines are placed at 30 pixel intervals.
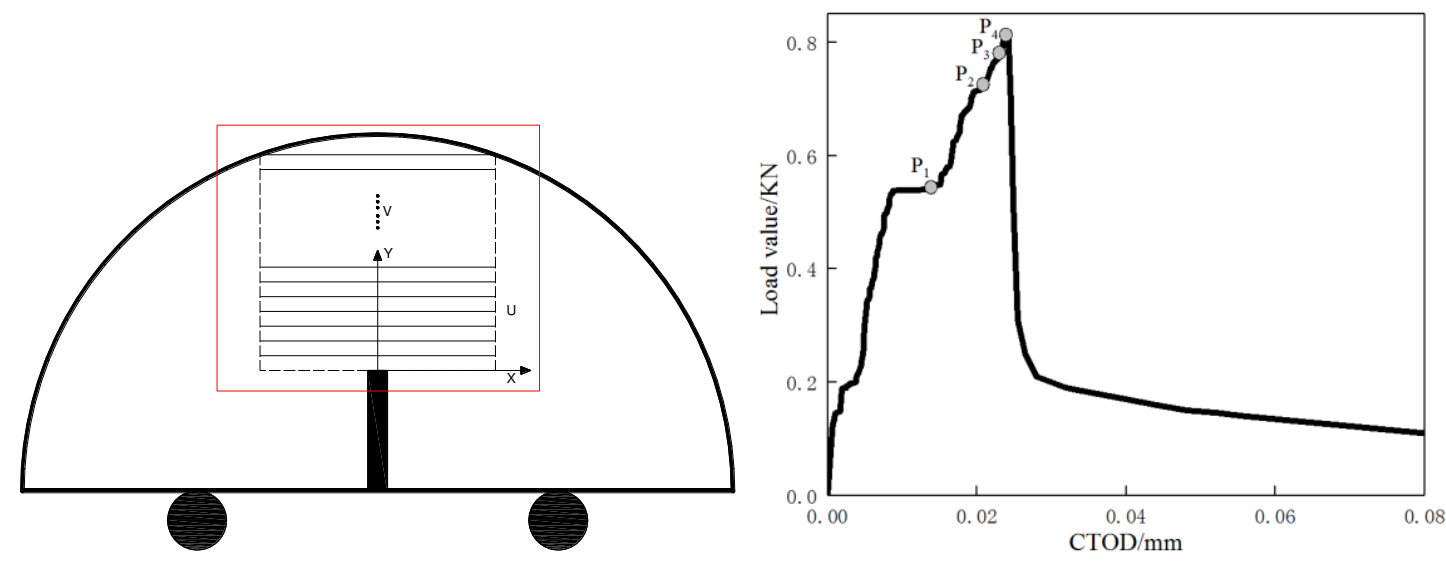

Fig. 8 Computational domains of SCB specimens

Fig. 9 P-CTOD at $0.7 \mathrm{~m}$ the borehole depth

\subsubsection{Determination of $P_{S}$ and $W_{0}$}

The CTOD can be obtained by analyzing the horizontal displacement $(\mathrm{u})$ at the crack tip of the prefabricated crack. Taking the coal at $0.7 \mathrm{~m}$ borehole depth as an example, $\mathrm{P}_{4}$ is the peak load (Fig. 9). Bounded by the peak load $\mathrm{P}_{4}$, the CTOD can be 
delimited into two stages. The slow growth stage before the peak and the rapid expansion stage after the peak. Although the CTOD of the first stage is very small, it is very important. because for nonlinear materials, the crack initiation point $\left(\mathrm{P}_{\mathrm{S}}\right)$ occurs in the first stage. The coal with strong plasticity in the plastic circle shows typical quasi brittle failure. In fact, in this test, the $\mathrm{P}_{\mathrm{S}}$ point of coal at $0.7 \mathrm{~m}$ borehole depth is $\mathrm{P}_{1}$ point, and $\mathrm{P}_{1}$ is far less than the $\mathrm{P}_{4}$. Therefore, there is a large error in the analysis of coal fracture behavior using LEFM method.

In order to Precisely obtain the $\mathrm{P}_{\mathrm{S}}$ point and the $\mathrm{W}_{0}$ of coal at different positions relative to the plastic circle, this test thoroughly analyzes the change in the crack tip opening displacement before load reaching the peak. The CTOD increases slowly in the initial loading stage, and viscous microcracks appear near the crack tip (Fig. 10). Then, with increasing load, the viscous microcracks propagate gradually. As the load continues to increase, the CTOD increases rapidly, resulting in a step-wise phenomenon. Results show that the attraction between atoms within the material at the notch tip disappears completely and the viscous microcracks at the crack tip propagate to form real cracks. According to the definition of the $\mathrm{W}_{0}$, the value corresponding to the real crack formation is designated $\mathrm{W}_{0}$. Therefore, through this test, the $\mathrm{P}_{\mathrm{S}}$ point and the $\mathrm{W}_{0}$ of coal at different positions relative to the plastic circle were obtained.

In Section 3.3, the experimental results show that the brittleness of coal at different positions relative to the plastic circle is significantly different. The P-CTOD curves are also significantly different, and they can be divided into three stages (Fig. 10). Taking the P-CTOD curve of coal at $0.7 \mathrm{~m}$ borehole depth as an example, the sequence is (I) viscous microcrack development; (II) rapid horizontal displacement of the crack tip; (III) real crack development stage. The loads at the crack initiation point of coal at 0.7 $\mathrm{m}, 2.5 \mathrm{~m}$, and $4.4 \mathrm{~m}$ borehole depth are $0.5262 \mathrm{KN}, 0.3818 \mathrm{KN}$, and $0.4701 \mathrm{KN}$, corresponding to $64.05 \%, 68.69 \%$, and $98.07 \%$ of the peak load, respectively (Table 6 ). The obvious difference is that the loads at the $\mathrm{P}_{\mathrm{S}}$ point of coal with weak brittleness in the plastic circle are less than the maximum load. While the load at the $\mathrm{P}_{\mathrm{S}}$ point of coal with strong brittleness outside the plastic circle is close to the maximum load. The CTOD shows the same pattern (Fig. 11). The CTOD is symmetrically distributed along the $\mathrm{X}$ axis. The $\mathrm{W}_{0}$ of coal at $0.7 \mathrm{~m}, 2.5 \mathrm{~m}$, and $4.4 \mathrm{~m}$ borehole depth are $0.0149 \mathrm{~mm}$, $0.0138 \mathrm{~mm}$, and $0.0115 \mathrm{~mm}$, accounting for $62.16 \%, 61.88 \%$, and $96.64 \%$ of that of maximum load, respectively. Coal with strong plasticity in the plastic zone undergoes significant material hardening during the loading process. Usually, before the stress reaches the peak, the crack has formed. With increasing borehole depth, the coal far from the plastic zone is close to brittle failure and the load at the $P_{S}$ point is close to the maximum load. Simultaneously, the $\mathrm{W}_{0}$ of coal with strong brittleness outside the plastic circle is smaller, making crack propagation is easier.

The previous analysis proved that a good linear relationship exists between the brittleness index and fracture toughness, and brittleness index can availably characterize the notch propagation ability of coal. Therefore, the brittleness index is linearly fit with the CTOD of the Ps point and the peak load point, respectively. The results are shown in Fig. 12. The linear fitting determination coefficient of the brittleness index and the CTOD of the $\mathrm{P}_{\mathrm{S}}$ point is 0.9533 , and the linear fitting 
determination coefficient of the brittleness index and the CTOD of maximum load point is 0.8305 . The method for determining the $\mathrm{W}_{0}$ of coal at different positions relative to the plastic circle obtained in this paper is effective. There may be a large deviation in analyzing the fracture feature of coal when using the CTOD based on the peak load.

The crack propagation path is shown in Fig. 13. Coal with a strong plasticity in the plastic circle displays a series of nonlinear phenomena such as microcrack propagation, material nonlinear deformation, crack surface contact, and friction in the FPZ. The internal energy is constantly lost and the material undergoes irreversible nonlinear damage until it is destroyed. The crack surface is rough and charges direction many times, making it easier to deviate from the initial propagation path. However, the crack surface of coal with strong brittleness outside the plastic circle is relatively smooth. The crack splits along a straight line due to the tensile stress perpendicular to the direction of the prefabricated crack. The crack initiation characteristics of coal at different positions relative to the plastic circle are quite different, demonstrating the necessity of analyzing the nonlinear fracture behavior of coal cracks.
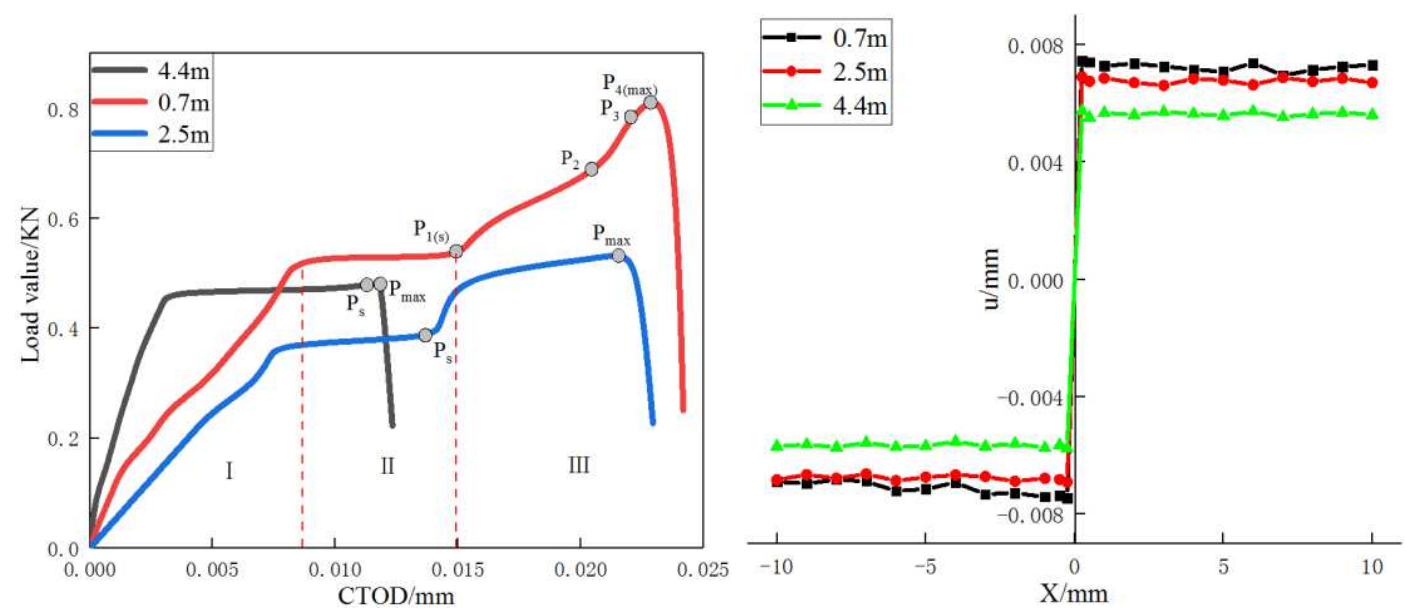

Fig. 10 P-CTOD curves for a crack tip in coal at different borehole depths

Fig. 11 Horizontal opening displacement of the crack tip at different borehole depths at the $\mathrm{P}_{\mathrm{S}}$ point
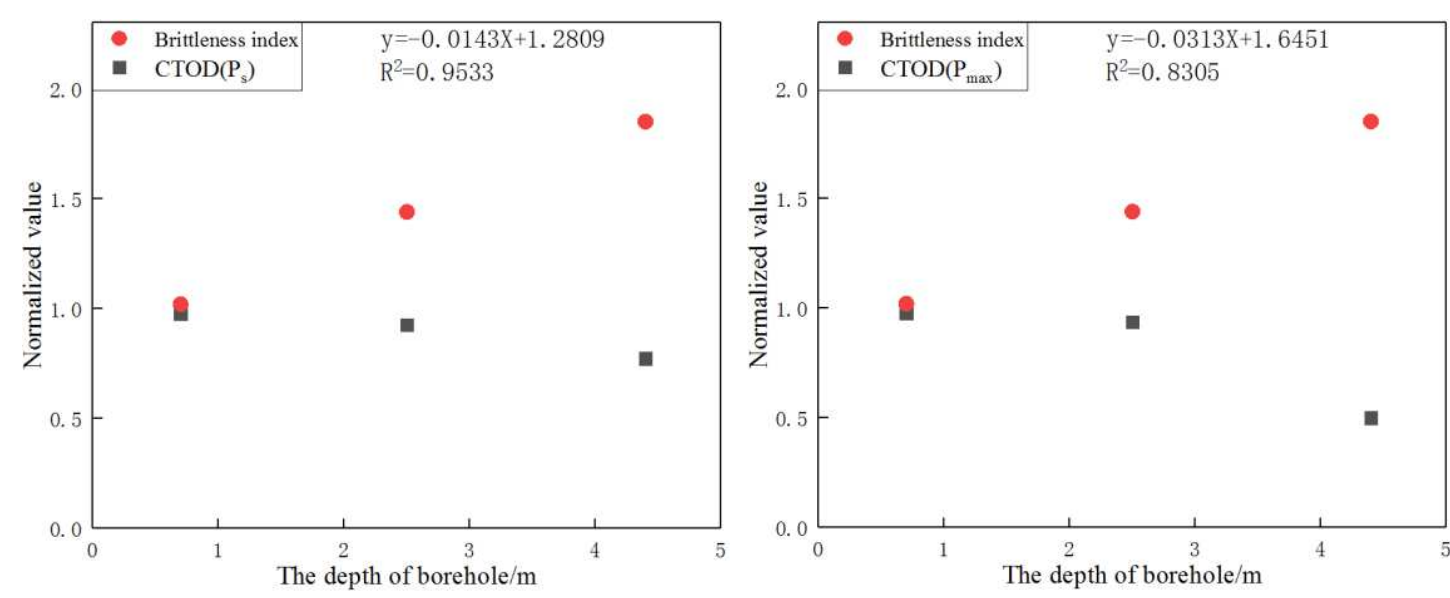

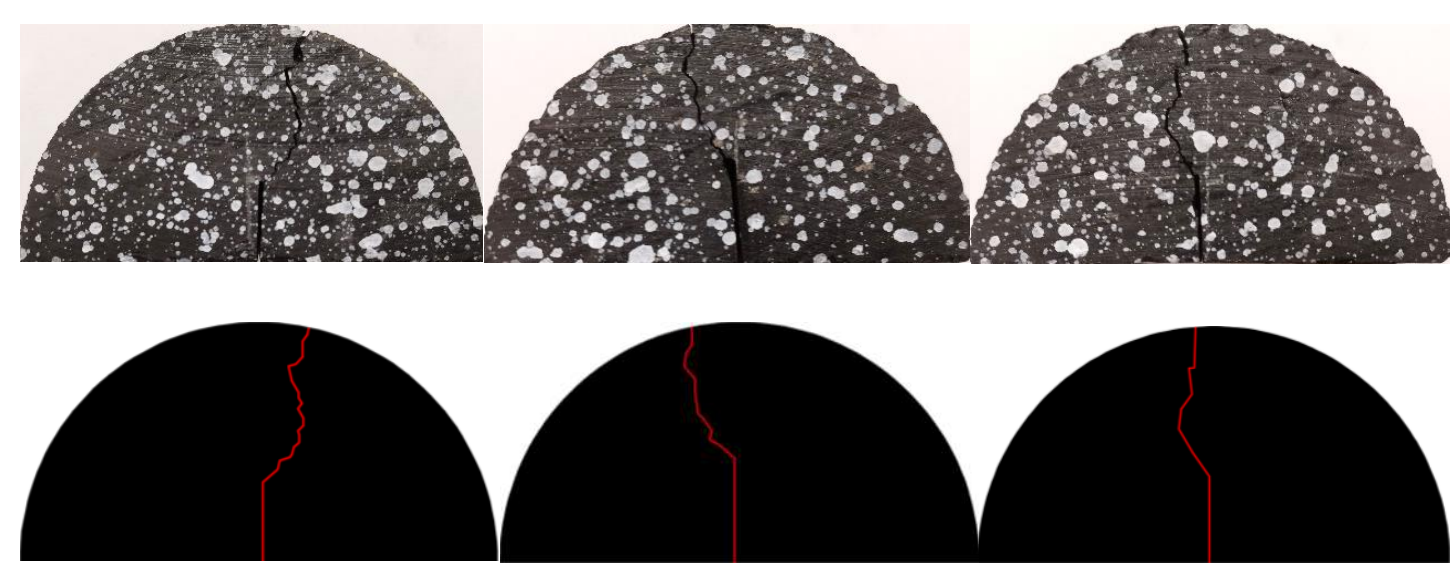

Fig. 13 The crack propagation path of coal at different borehole depths

Table 6 The load and CTOD at the Ps point and load peak point

\begin{tabular}{cccccccc}
\hline Sampling positions & $\begin{array}{c}\text { Borehole } \\
\text { depth } / \mathrm{m}\end{array}$ & $\begin{array}{c}\text { Load }\left(\mathrm{P}_{\mathrm{s}}\right) \\
/ \mathrm{KN}\end{array}$ & $\begin{array}{c}\text { Load }\left(\mathrm{P}_{\max }\right) \\
/ \mathrm{KN}\end{array}$ & $\begin{array}{c}\text { ratio } \\
/ \%\end{array}$ & $\begin{array}{c}\text { CTOD }\left(\mathrm{P}_{\mathrm{s}}\right) \\
/ \mathrm{mm}\end{array}$ & $\begin{array}{c}\text { CTOD }\left(\mathrm{P}_{\max }\right) \\
/ \mathrm{mm}\end{array}$ & $\begin{array}{c}\text { ratio } \\
/ \%\end{array}$ \\
\hline In the plastic circle & 0.7 & 0.5262 & 0.8215 & 64.05 & 0.0149 & 0.0238 & 62.61 \\
Edge of plastic circle & 2.5 & 0.3818 & 0.5558 & 68.69 & 0.0138 & 0.0223 & 61.88 \\
Out the plastic circle & 4.4 & 0.4701 & 0.4813 & 98.07 & 0.0115 & 0.0119 & 96.64 \\
\hline
\end{tabular}

\subsubsection{The evolution process of the FPZ}

The coal in the plastic circle shows typical nonlinear failure, while coal out the plastic circle undergoes near brittle failure. Different brittle coals show different crack propagation processes, which are related to the size of the FPZ and the propagation of microcracks during nonlinear failure. Therefore, we analyze the FPZ evolution for coal in the plastic circle to understand the nonlinear fracture process of coal. When the initial CTOD is less than the $\mathrm{W}_{0}$, no real crack is formed, and the FPZ continuously develops from crack tip upward. When load increases to the value of $\mathrm{P}_{1}$ point, the CTOD just reaches the $\mathrm{W}_{0}$, and the FPZ is completely formed (Fig. 14a). The length of the FPZ can be determined by locating the viscous crack tip. As the load continues to increase, the CTOD increases, and both the FPZ end and the real crack tip move forward (Fig. 14b). The length of the FPZ is the distance from the end of the FPZ to the real crack tip. In this study, the length of the FPZ of $\mathrm{P}_{\mathrm{S}}\left(\mathrm{P}_{1}\right)$ point is $5.27 \mathrm{~mm}$, and the lengths of the FPZ of $\mathrm{P}_{2}, \mathrm{P}_{3}$, and maximum load $\left(\mathrm{P}_{4}\right)$ are $5.45 \mathrm{~mm}, 5.52 \mathrm{~mm}$, and $5.77 \mathrm{~mm}$ respectively (Fig. 15). Before the stress reaches the maximum value, the position of the FPZ keeps moving towards the upper end of the specimen, while the length increases gradually, nonlinear failure area increases, and crack propagation process becomes more difficult. Therefore, even after the $\mathrm{P}_{\mathrm{S}}\left(\mathrm{P}_{1}\right)$ point, the load will still increase, providing more energy.

Fig. 16 shows the change in the length of the FPZ, crack growth, and total crack length of coal at $0.7 \mathrm{~m}$ borehole depth. With increasing load, the crack growth length 
increases. The crack propagation length at the $\mathrm{P}_{\mathrm{S}}\left(\mathrm{P}_{1}\right)$ point is equal to the length of the FPZ, which is $5.27 \mathrm{~mm}$, accounting for $23.16 \%$ of the distance from the crack tip to the specimen tip. The crack growth length of the maximum load $\left(\mathrm{P}_{4}\right)$ is the sum of the new real crack length and the length of the FPZ, which is $10.08 \mathrm{~mm}$, accounting for $44.31 \%$ of the distance from the top of the prefabricated crack to the top of the specimen. The difference was $91.27 \%$, proving that the nonlinear fracture behavior of coal with strong plasticity in the plastic circle is significant, and large errors occur when the linear method is used to analyze the fracture toughness and fracture behavior the coal.

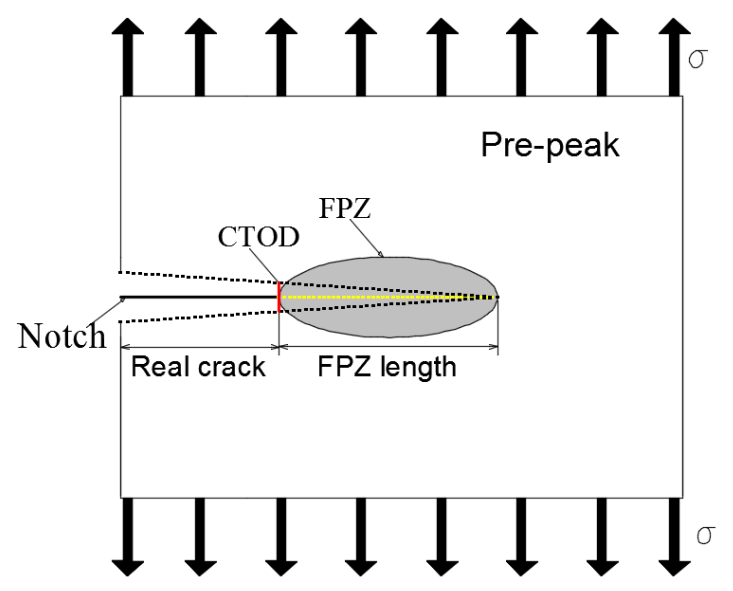

Fig.14a P1 load

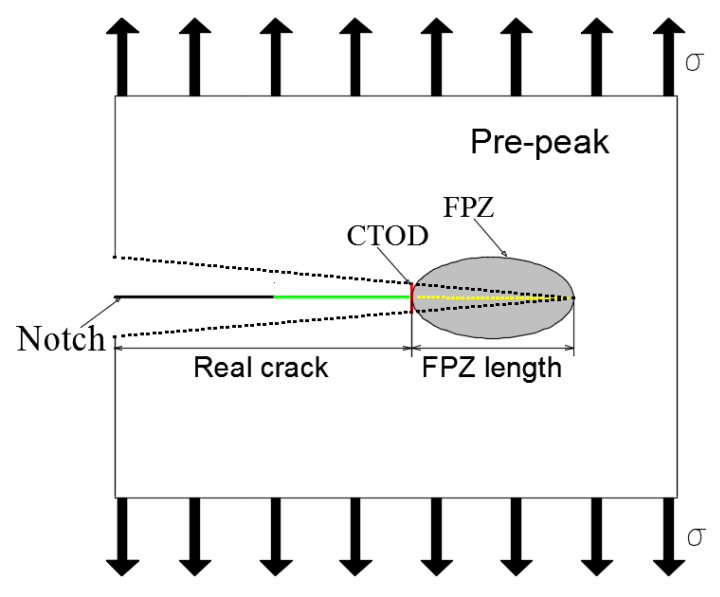

Fig.14b After P1 load

Fig. 14 Cohesive crack model
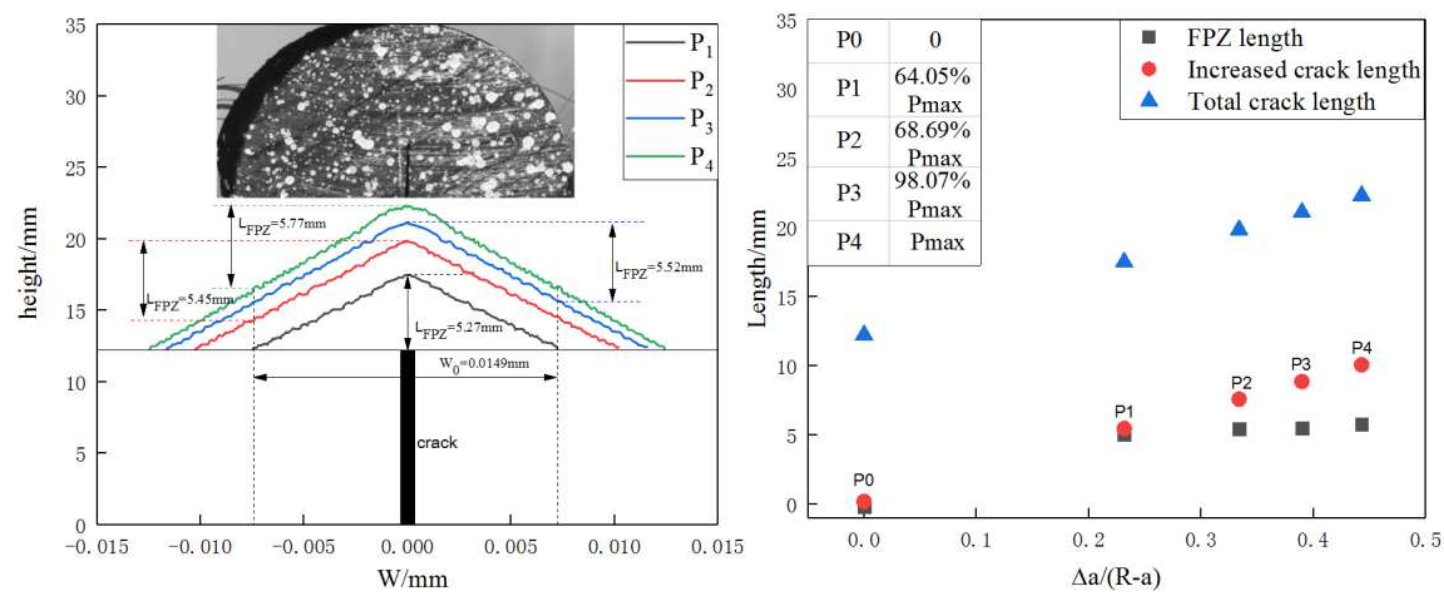

Fig. 15 The FPZ evolution process of coal at $0.7 \mathrm{~m}$ borehole depth

Fig. 16 Variation of FPZ and crack length

\section{Conclusions}

(1) The strength parameters of coal at different positions relative to the plastic circle of roadway surrounding rock are quite different. In this experiment, the deeper borehole is, the greater the compressive strength and elastic modulus of coal are, but the tensile strength and Poisson's ratio show the opposite trend. With increasing borehole depth, the coal outside the plastic zone becomes harder and more brittle, which is more easily produce cracks and expand rapidly under non-uniform stress. 
(2) The $K_{\mathrm{IC}}$ of coal varies significantly at different positions relative to the plastic zone of roadway surrounding rock. The deeper borehole is, the smaller the $K_{\mathrm{IC}}$ of coal is. The $\mathrm{K}_{\mathrm{Ic}}$ of coal at $0.7 \mathrm{~m}, 2.5 \mathrm{~m}$, and $4.4 \mathrm{~m}$ borehole depth is $0.2436 \mathrm{MPa}, 0.1736$ $\mathrm{MPa}$, and $0.1504 \mathrm{MPa}$, respectively. Compared with compressive strength, the linear correlation between $\mathrm{K}_{\mathrm{I}}$ and tensile strength of coal is higher. Elastic modulus can reflect the supporting capacity of coal after fracturing, and Poisson's ratio can reflect the fracture capacity of coal under stress. Compared with the elastic modulus, Poisson's ratio has a stronger influence on crack growth and has a stronger correlation with the $K_{\mathrm{I}}$ of coal. There is a linear relationship between brittleness and $\mathrm{K}_{\mathrm{Ic}}$ of coal, which can be characterized by the strength of coal brittleness.

(3) When studying the mode I crack propagation characteristics of coal, at a certain time before the stress reaches the peak value, the CTOD increases rapidly, forming a horizontal step, and the viscous microcrack expands rapidly to form a real crack. According to the definition of CTOD, we consider that the CTOD is the $\mathrm{W}_{0}$ when the real crack is formed. Based on this, the accurate $\mathrm{P}_{S}$ point and the $\mathrm{W}_{0}$ of different brittle plastic coals are obtained. Compared with existing experimental methods and numerical simulations, the $\mathrm{W}_{0}$ obtained by this method is more accurate because it is closer to using $\mathrm{W}_{0}$ to analyze the crack growth process. By using the method defined in this paper, the $\mathrm{W}_{0}$ of coal at $0.7 \mathrm{~m}, 2.5 \mathrm{~m}$, and $4.4 \mathrm{~m}$ borehole depth are $0.0149 \mathrm{~mm}, 0.0138 \mathrm{~mm}$, and $0.0115 \mathrm{~mm}$, respectively. The $\mathrm{K}_{\mathrm{Ic}}$ of coal with stronger brittleness outside the plastic zone allows for easier crack propagation.

(4) The coal in the shallow part of borehole has strong plasticity, and the load at the $\mathrm{P}_{\mathrm{S}}$ point of coal with $0.7 \mathrm{~m}$ borehole depth is only $64.05 \%$ of the maximum load. With increasing borehole depth, the more brittle the coal is, the closer it is to elastic failure. The load at the $P_{S}$ point of coal at $4.4 \mathrm{~m}$ borehole depth is $98.07 \%$ of the maximum load. The load of $\mathrm{P}_{\mathrm{S}}$ points for different brittle plastic coals are significantly different. The linear fitting determination coefficient of brittleness index and the CTOD of the $\mathrm{P}_{\mathrm{S}}$ point is 0.9533 , and the linear fitting determination coefficient of brittleness index and the CTOD of maximum load point is 0.8305 . The method for determining the $W_{0}$ of coal at different positions relative to the plastic circle obtained in this paper is effective. There may be a large deviation in analyzing the fracture behavior of coal when using the CTOD of the maximum load.

(5) The coal with strong plasticity in the plastic circle shows a series of nonlinear phenomena such as microcrack propagation, material nonlinear deformation, crack surface contact, and friction in the FPZ. The internal energy is constantly lost, and the material undergoes irreversible nonlinear damaged until it is destroyed. The crack surface is rough and changes direction many times, which makes it easier to deviate from the initial propagation path. However, the crack surface of coal with strong brittleness outside the plastic circle is relatively smooth. The crack splits along a straight line due to the tensile stress perpendicular to the direction of the prefabricated crack. Different brittle coals show different crack propagation processes, which are related to the size of the FPZ and the propagation of microcracks during nonlinear failure. 


\section{Acknowledgement}

Thanks to funds supported by the National Natural Science Foundation of China (No. 51174280, No. 51804244 and No.41027002). And thanks to funds supported by the National Science Foundation for Young Scientists of China (No. 52004203). The author would also like to thank Professor Chai and Professor Yang for participating in the model test and for valuable comments and suggestions on the improvement of the manuscript. Otherwise, this study would not to be so smooth implementation without them.

\section{Conflict of interest}

\section{Dear Editors:}

We declare that the paper we submit do not have a conflict of interest with any personal, commercial or associative.

\section{References}

1. Hill R. The Mathematical Theory of Plasticity. Oxford: Oxf Univ Press;1950.

2. Leitman MJ, Villaggio P. Plastic zone around circular holes. Eng Mech 2009;135(12):1467-1471.

3. Chen LW, Peng JB, Fan W, Sun P. Analysis based on unified strength theory of non-uniform stress field circular roadway for plastic zone. China Coal Soc 2007;32(1):20-30.

4. Zhao ZQ. Study on mechanism and control method of deformation and failure of surrounding rock in large deformation mining roadway. Beijing: China Univ Min Tech (Beijing); 2014.

5. Wu LR, Jiang ZA, Chen WM, Zuo XW, Lv DW, Yao YJ. Major accident analysis and prevention of coal mines in China from the year of 1949 to 2009. Min Sci Tech 2011;21(5):693-699.

6. Zou H, Yan EC. The surrounding rock deformation and failure mechanism of Wudang group schists roadway. Elec J Geot Eng 2015;20(11):6557-6576.

7. Lee KH, Kai DH, Park JJ, Lee IM. A study on critical strain based damage controlled test for the evaluation of rock roadway stability. Kor Tunn Undergr Spa Associ 2011;13(6):501-517.

8. Lajtai E Z. A theoretical and experimental evaluation of Griffith theory of brittle fracture. Tectonophysics, 1971, 11(2): 129-156.

9. Bazant Z P. Crack band theory for fracture of concrete. Mater Struct, 1983, 16(2): 155-177.

10. Santiago S D, Hilsdorf H K. Fracture mechanism of concrete under compressive loads. Cem Concr Res, 1973, 3(4): 363-388

11. Ebrahimi M E, Chevalier J, Fantozzi G. Slow crack growth behavior of alumina ceramics. J Mater Res, 2000, 15(1): 142-147.

12. Nemat N S, Horii H. Compression induced non-planar crack extension with application to splitting, exfoliation and rock bursts. J Geophys Res, 1982, 87(B8): 6805-6821.

13. Melin S. When does a crack grow under mode II conditions. Int J Frac, 1986, 30(1): 103-104.

14. Palumbo D, Finis RD, Ancona F, Galietti U. Damage monitoring in fracture mechanics by evaluation of the heat dissipated in the cyclic plastic zone ahead of the crack tip with thermal measurements. Eng Frac Mech 2017;181:65-76.

15. Paul SK. Numerical models of plastic zones and associated deformations for elliptical inclusions in remote elastic loading-unloading with different R ratios. Eng Frac Mech 2016;152:72-80.

16. Hao Zhang, Donghui Fu, Haipeng Song, Yilan Kang, Ganyun Huang, Gang Qi, Jianyu Li. Damage and Fracture Investigation of Three-Point Bending Notched Sandstone Beams by DIC and AE Techniques. Rock Mech Rock 
Eng,2015,48(3).

17. Jianfeng Yang, Haojie Lian, Weiguo Liang, Vinh P N, Yuedu Chen. Experimental investigation of the effects of supercritical carbon dioxide on fracture toughness of bituminous coals. Int J Rock Mech Min Sci,2018,107.

18. Hoover CG, Bažant ZP. Cohesive crack, size effect, crack band and work of fracture models compared to comprehensive concrete fracture tests. Int J Frac 2014;187(1):133-143.

19. Dongyang Li, Peiyan Huang, Zhanbiao Chen, Guowen Yao, Xinyan Guo, Xiaohong Zheng, Yi Yang. Experimental study on fracture and fatigue crack propagation processes in concrete based on DIC technology. Eng Frac Mech,2020,235.

20. Wei Dong, Zhimin Wu, Xiangming Zhou, Na Wang, Gediminas K. An experimental study on crack propagation at rock-concrete interface using digital image correlation technique. Eng Frac Mech,2017,171.

21. Sujatha V, Kishen JMC. Energy release rate due to friction at bimaterial interface in dams. Eng Mech 2003;129:793-800.

22. Yang S, Song L, Li Z, Huang S. Experimental investigation on fracture toughness of interface crack for rock/concrete. Int J Mod Phys B 2008;22:6141-6148.

23. Lin $Q$, Labuz JF. Fracture of sandstone characterized by digital image correlation. Int J Rock Mech Min Sci 2013;60:235-245

24. Petersson PE. Crack growth and development of fracture zones in plain concrete and similar materials Report TVBM-1006. Sw: Divi Buil Mater, Lund Inst Tech; 1981.

25. Dong $\mathrm{W}, \mathrm{Wu} Z$, Zhou X. Fracture mechanisms of rock-concrete interface: experimental and numerical. Eng Mech, ASCE 2016;142:04016040.

26. Bažant ZP, Oh BH. Crack band theory for fracture of concrete. Mater Struct 1983;16(3):155-177.

27. Ba Zant ZP, Kazemi MT. Determination of fracture energy, process zone length and brittleness number from size effect, with application to rock and concrete. Int J Frac 1990;44(2):111-131.

28. Haggerty M, Qing Lin J, Labuz F. Observing Deformation and Fracture of Rock with Speckle Patterns. Rock Mech Rock Eng,2010,43(4).

29. Jing Chai, Zhe Ma, Dingding Zhang, Qiang Yuan, Wulin Lei. Experimental study on PPP-BOTDA distributed measurement and analysis of mining overburden key movement characteristics. Opti Fiber Tech,2020,56.

30. Diyuan Li, Quanqi Zhu, Zilong Zhou, Xibing Li, Ranjith PG. Fracture analysis of marble specimens with a hole under uniaxial compression by digital image correlation. Eng Frac Mech,2017.

31. Wu Z, Rong H, Zheng J, Xu F, Dong W. An experimental investigation on the FPZ properties in concrete using digital image correlation technique. Eng Frac Mech 2011;78:2978-2990.

32. Alam SY, Saliba J, Loukili A. Fracture examination in concrete through combined digital image correlation and acoustic emission techniques. Constr Build Mater 2014;69:232-242.

33. Enfedaque A, Gálvez JC, Suárez F. Analysis of fracture tests of glass fiber reinforced cement (GRC) using digital image correlation. Constr Build Mater 2015;75:472-487.

34. Trivedi N, Singh RK, Chattopadhyay J. Investigation on fracture parameters of concrete through optical crack profile and size effect studies. Eng Frac Mech 2015;147:119-139.

35. Lin Q, Yuan H, Biolzi L, Labuz JF. Opening and mixed mode fracture processes in a quasi-brittle material via digital imaging. Eng Frac Mech 2014;131:176-193.

36. Shah SG, Kishen JMC. Fracture properties of concrete-concrete interfaces using digital image correlation. Exp Mech 2011;51:303-313.

37. Ayatollahi MR, Aliha MRM. Fracture parameters for a cracked semi-circular specimen. Int J Rock Mech Min Sci. 2004;41:20-25.

38. Li Jiangteng, Gu Desheng, Cao Ping. Interrelated law between mode I fracture toughness and compression 
strength of rock. J Cent S Univ (Sci Tech), 2009, 40(6): 1695-1699.

39. Golshani, Allakbar, Okui Y, et al. A micromechanical model for brittle failure of rock and its relation to crack growth observed in triaxial compression tests of granite. Mech Mater, 2006, 38(4): 287-303.

40. Golshani, Allakbar, Oda M, et al. Numerical simulation of the excavation damaged zone around an opening in brittle rock. Int J Rock Mech Min Sci, 2007, 44(6): 835-845.

41. Li Qinghui, Chen Mian, Jin Yan. Indoor evaluation method for shale brittleness and improvement. Chin J Rock Mech Eng, 2012,32(8):1680-1685.

42. Hucka V, Das B. Brittleness determination of rocks by difference methods. Int J Rock Mech Min Sci Geomech Abst, 1974, 11(10):389-392.

43. Altindag R. Correlation of specific energy with rock brittleness concepts on rock cutting. J S Afr Inst Min Metall, 2013,103(3):163-171.

44. Andreev GE. Brittle failure of rock materials: test results and constitutive models. Rot,1995:123-127.

45. Bishop AW. Progressive failure with special reference to the mechanism causing it//Proc Geotech Conf, Olso: [s.n.],1967:142-150.

46. Hajiabdolmajid V, Kaiser P. Brittleness of rock and stability assessment in hard rock tunneling. Tunn Undergr Space Tech, 2013, 18(1):35-48.

47. Copur H, Bilgin N, Tuncdemir H. A set of indices based on indentation test for assessment of rock cutting performance and rock properties. J S Afr Inst Min Metall,2003,103(9):589-600.

48. Yagiz S. An investigation on the relationship between rock strength and brittleness//Proc Tur. Ank, Tur,2006:352.

49. Honda H, Sanada Y. Hardness of coal. Fuel, 1956,35:451.

50. Lawn BR, Marshall DB. Hardness, toughness and brittleness: an indentation analysis. J Am Ceram Soc,1979,62(7/8):347-350.

51. Quinn JB, Quinn GD. Indentation brittleness of ceramics: a fresh approach. J Mater Sci,1997,32(16):4331-4346.

52. Protodyakonov MM. Mechanical properties and drill ability of rocks//Proc $5^{\text {th }}$ Symp Rock Mech. TC, USA: Univ MN Press,1963:103-118.

53. Ingram GM, Urai JL. Top-seal leakage through faults and fractures: the role of mudrock properties. Geol Soc,1999,158(1):125-135.

54. Rickman R, Mullen M, Peter E, et al. A practical use of shale petrophysics for stimulation design optimization: all shale plays are not clones of the Barnett Shale. Soc Petrol Eng. 2008,115258. 